\title{
Pathogens and Related Diseases in Non-European Cephalopods: Central and South America
}

\author{
Yanis Cruz-Quintana, Jonathan Fabricio Lucas Demera, \\ Leonela Griselda Muñoz-Chumo, Ana María Santana-Piñeros, \\ Sheila Castellanos-Martínez, and Ma. Leopoldina Aguirre-Macedo
}

\begin{abstract}
Despite the economic and ecologic importance of Mexican four-eyed Octopus maya and the jumbo squid Dosidicus gigas, the pathogens and diseases in both species remain largely unknown. This chapter covers the pathogens and diseases, mainly protozoan and metazoan parasites, of these two non-European cephalopods.
\end{abstract}

Keywords

Mexico • Ecuador • Fisheries • Parasites • Octopus maya • Dosidicus gigas

\subsection{Introduction}

The Mexican four-eyed Octopus maya and the jumbo squid Dosidicus gigas are important fishery sources from Mexico and Ecuador, respectively. Octopus maya is an endemic species of the Yucatan peninsula, with a distribution range

Y. Cruz-Quintana $(\bowtie) \cdot$ J. F. Lucas Demera .

L. G. Muñoz-Chumo - A. M. Santana-Piñeros

Grupo de Investigación en Sanidad Acuícola, Inocuidad y Salud Ambiental. Escuela de Acuicultura y Pesquería, Facultad de Ciencias Veterinarias, Universidad Técnica de Manabí, Calle Gonzalo Loor Velasco, S/N., Ciudadela Universitaria, CP 130104 Bahía de Caráquez, Ecuador

e-mail: cqyanis@gmail.com

J. F. Lucas Demera

e-mail: jonathanlucas17@outlook.com

L. G. Muñoz-Chumo

e-mail: leitogris@gmail.com

A. M. Santana-Piñeros

e-mail: anasantana4@gmail.com

S. Castellanos-Martínez

Instituto de Investigaciones Oceanológicas UABC, Ensenada,

Mexico

e-mail: mixtly2000@hotmail.com

Ma. L. Aguirre-Macedo

Laboratorio de Patología Acuática y Parasitología, CINVESTAV

Unidad Mérida, Carretera Antigua a Progreso, Km 6, Cordemex,

97310 Mérida, Yucatán, Mexico

e-mail: leopoldina.aguirre@cinvestav.mx spanning from Ciudad del Carmen in Campeche State to Isla Mujeres in Quintana Roo State (Van Heukelem 1983). It is one of the most important commercially exploited species in Mexican fisheries, generating over 27 million dollars in revenue annually, with a high potential for aquaculture due to their good adaptability to captive conditions. On the other hand, D. gigas is an endemic species of the eastern Pacific, with a distribution range going from Alaska, USA, to Tierra del Fuego, Chile (Roper et al. 2010). It is commercially caught by the USA, México, Perú, and Chile. However, in early 2014, the Ecuador Government decided that $D$. gigas must be a new fishery target and the collection of biological data to improve the fisheries management began (Morales-Bojórquez and Pacheco-Bedoya 2016). In this chapter, an overview of the parasites and pathological conditions in two wild cephalopods, the Octopodidae Octopus maya from the Mexican Caribbean coast and the Ommastrephidae Dosidicus gigas from the Ecuadorian Pacific coast, is provided. Tissue slides collected from both species were stained with hematoxylin and eosin (H\&E). The figures include the scale bar in micrometers, except in the majority of the macroscopic images which include the scale in millimeters. In this chapter, we will not go into detail on the anatomy and normal histology of Octopus maya or Dosidicus gigas, as these general aspects of cephalopods have been addressed previously in Chaps. 3 and 4. However, we will describe some anatomical and histological aspects of the affected organs or tissues, to facilitate the understanding of the tissue alterations. 


\subsection{Pathogens and Related Diseases in the Mexican Four-Eyed Octopus Octopus Maya}

The digestive tract of $O$. maya, like other octopuses, is rather short, consisting of a buccal mass, esophagus, crop, stomach, caecum, intestine, and digestive gland. The buccal mass, the first organ of the digestive system, is a roughly spherical structure that lies just in front of the brain, within a sinus formed by the base of the arms (Fig. 17.1a). It is loosely attached within the sinus by the esophagus and the enclosing buccal membrane, a pigmented web of folded skin that is attached to the arms. The buccal membrane surrounding the beaks is folded into inner and outer lips. Among other components like muscles, radula, and upper and lower beaks, the buccal mass involves the anterior salivary glands (Fig. 17.1b), a simple branched tubular gland surrounded by a thin capsule of lax connective tissue with scarce muscular fibers. The secretory epithelium of this gland is supported by a connective tissue membrane which forms trabecules within the tissue. Acinar spaces are formed and lined with secretory cells that vary in height, from cuboidal to columnar depending on the stage of secretion (Fig. 17.1c). The function of the mucus produced by the anterior salivary glands is not only limited to the provision of lubrication necessary for sliding and predigestion of the food but also provides support for eggs in spawning females.
Larval stages of the cestoda Prochristianella hispida infect the anterior salivary glands of $O$. maya, destroying the secretory tissue and producing fibrosis. In hosts with low infection $(<5$ parasites), the cestodes cause focal necrosis of the tubules' epithelial tissue, with a slight proliferation of connective tissue (Fig. 17.1d). In moderate infections (6-20 parasites), damage is more noticeable, compromising larger areas (Fig. 17.2a), whereas in heavy infections ( $>20$ parasites per host), the secretory epithelium is replaced by parasites and fibrous connective tissue (Fig. 17.2b), which reduces the functionality of the gland. The parasites also infect, although in less number, the scarce connective tissue between the internal and external epithelium and muscles of the buccal mass. The high prevalence of cestode larvae in the anterior salivary glands of $O$. maya and the severe damages associated with the infection level could cause reproductive and nutritional alterations, considering the functions of saliva in these two physiological processes.

Continuing through the digestive tract and posterior to the buccal mass, esophagus, crop, and stomach, the caecum is located; a tubular organ spirals around an axis or columella (Fig. 17.3a). The caecum shows longitudinal folds protruding into the lumen, increasing the surface area of the organ. In the external wall of the caecum, these folds are larger and more abundant than those in the internal wall near the columella. These primary folds that arise from the inner side of the external wall give way to secondary folds. They are all
Fig. 17.1 a Octopus maya dissected, showing the digestive system: buccal mass (arrow), esophagus, posterior salivary glands, intestine, stomach, and caecum. The digestive gland (DG) was removed to facilitate the organs' visibility. Scale bar: $50 \mathrm{~mm}$. b Buccal mass with anterior salivary glands (arrow). c Anterior salivary glands showing: cylindrical cells (arrows), lumen (1). Scale bar: $50 \mu \mathrm{m}$. d Anterior salivary glands with low cestode infection. Note the normal appearance of the secretory tissue (lower right) despite the presence of two cestodes (c). Scale bar: $500 \mu \mathrm{m}$
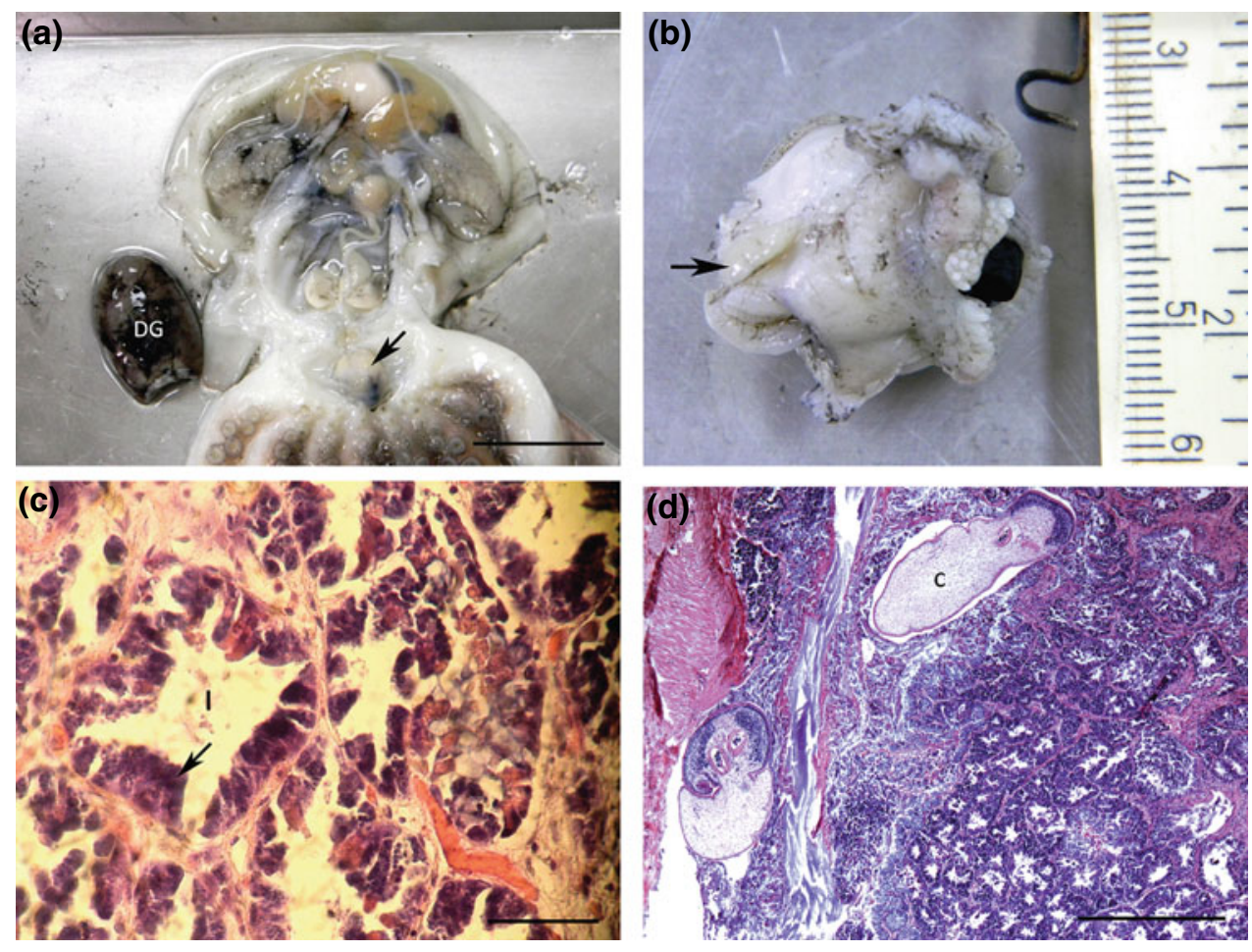
Fig. 17.2 Anterior salivary glands with cestode (c) infection. a Moderate infection, observing the proliferation of connective tissue (arrow) and loss of secretory tissue (lower left). Scale bar: $500 \mu \mathrm{m}$. b Heavy infection where secretory tissue has been replaced by cestodes and fibrous connective tissue. Scale bar: $500 \mu \mathrm{m}$
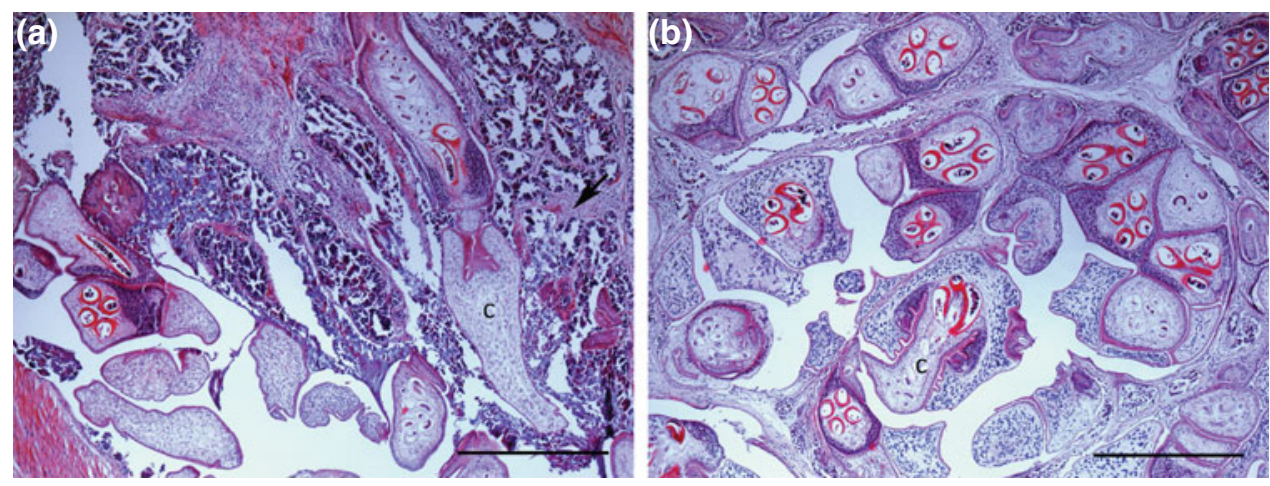

lined by a simple, cylindrical, and ciliated epithelium, and have a central axis of loose connective tissue (or corion) with high vascularization (Fig. 17.3b). The mucosa is underlined by scarce connective tissue and thin fascicles of longitudinal muscle fibers. A similar architecture is shown in the intestine, which has longitudinal folds protruding into the lumen mainly in the proximal and medial zones. The mucosa is lined by a pseudostratified and ciliated epithelium that lies on a loose, highly vascularized connective tissue with some muscle fibers. Behind the connective tissue, a thin muscular wall comprised by an external circular layer and an internal longitudinal one provides the support and elasticity to the intestine.
As found in Octopus vulgaris (Estévez et al. 1996; Gestal et al. 1999, 2002), coccidian of the genus Aggregata infects the wall and primary folds in the caecum and intestine of Octopus maya. Small and whitish cysts containing Aggregata sporocysts are easily distinguished in the external wall of both organs by gross observation (Fig. 17.3a). Histologically, gamogony and sporogony of Aggregata sp. are observed in the loose connective tissue and epithelium of the primary folds. The presence of macro- and microgametes cause enlargement, not only in the infected cells but also in the primary folds (Fig. 17.4a). Frequently, these marked enlargements cause rupture of the basal membrane with the detachment of the epithelium.
Fig. 17.3 a Dorsal view of the stomach(s) and caecum coiled (ca) of O. maya. Oocyst of Aggregata sp. (arrow) in the external wall of the caecum coiled. b Normal histology of the caecum coiled showing the external wall with primary longitudinal folds, with different heights (arrows), and secondary folds (arrowhead). (m) Muscle of external wall. Scale bar: $200 \mu \mathrm{m}$
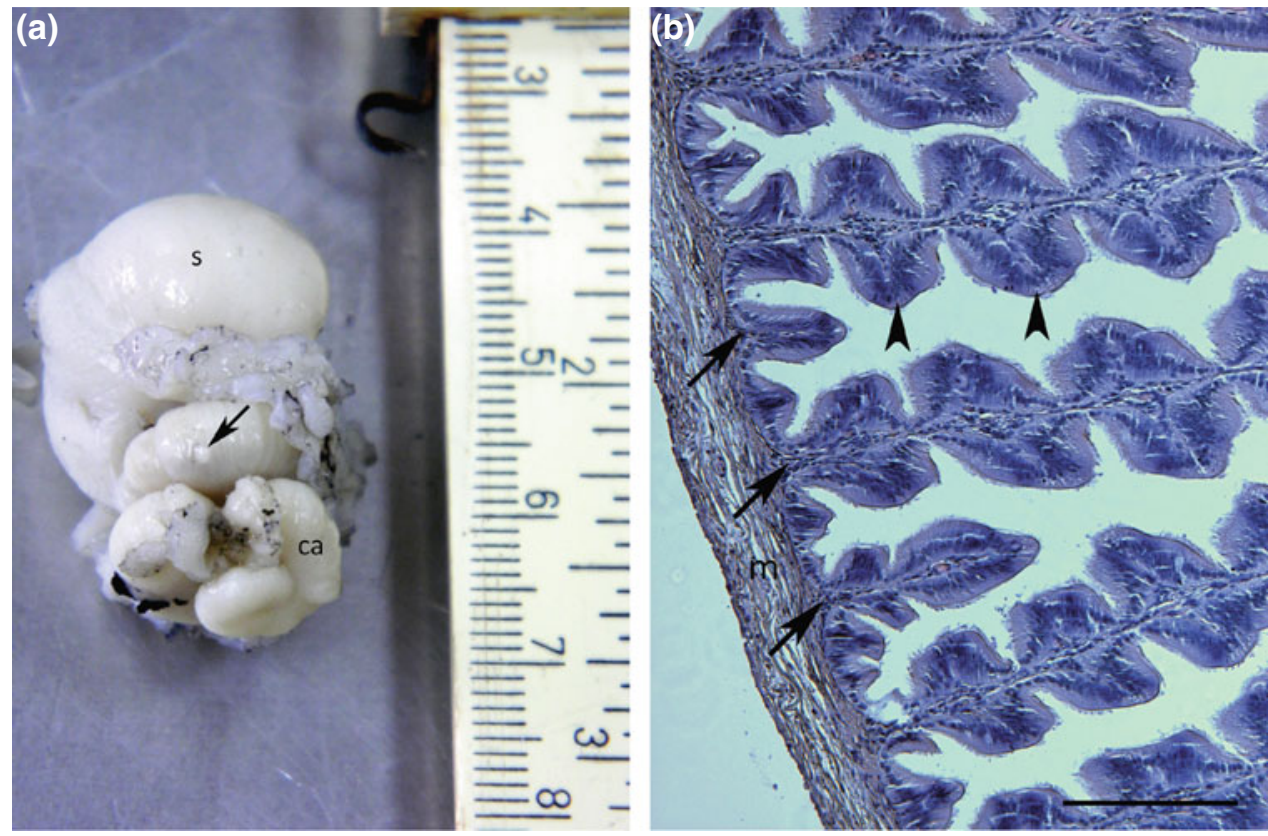

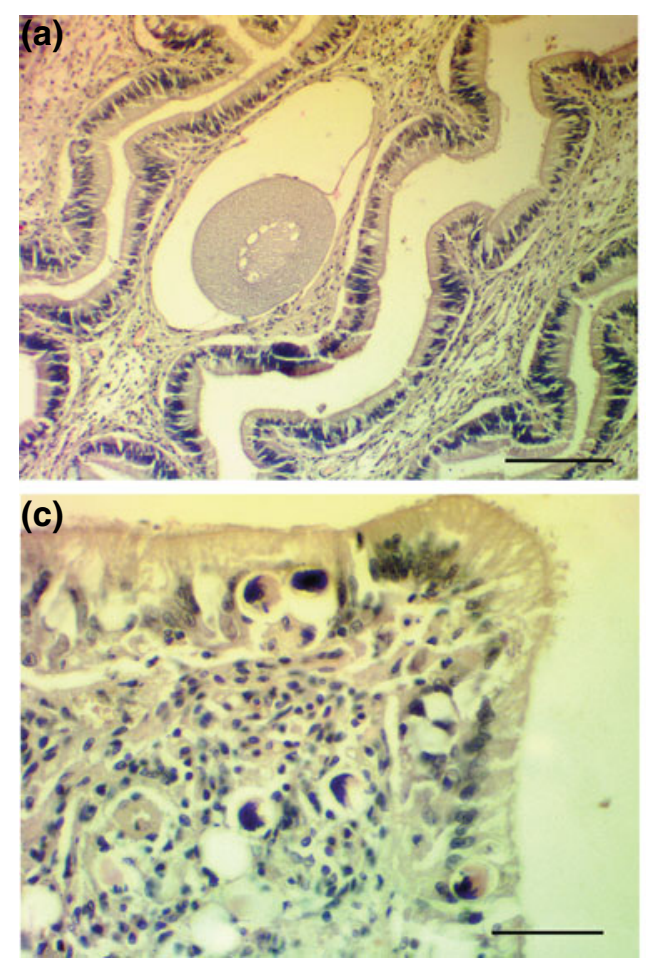

Fig. 17.4 a Histological section of macrogametes on an infected caecum of $O$. maya. Scale bar: $200 \mu \mathrm{m}$. b Histological section of sporocyst located on the loose connective tissue of an infected caecum of $O$. maya. The presence of sporocysts causes hemocytic infiltration and distension of the primary folder. Scale bar: $200 \mu \mathrm{m}$. c The histological section at a higher magnification of the infected caecum as
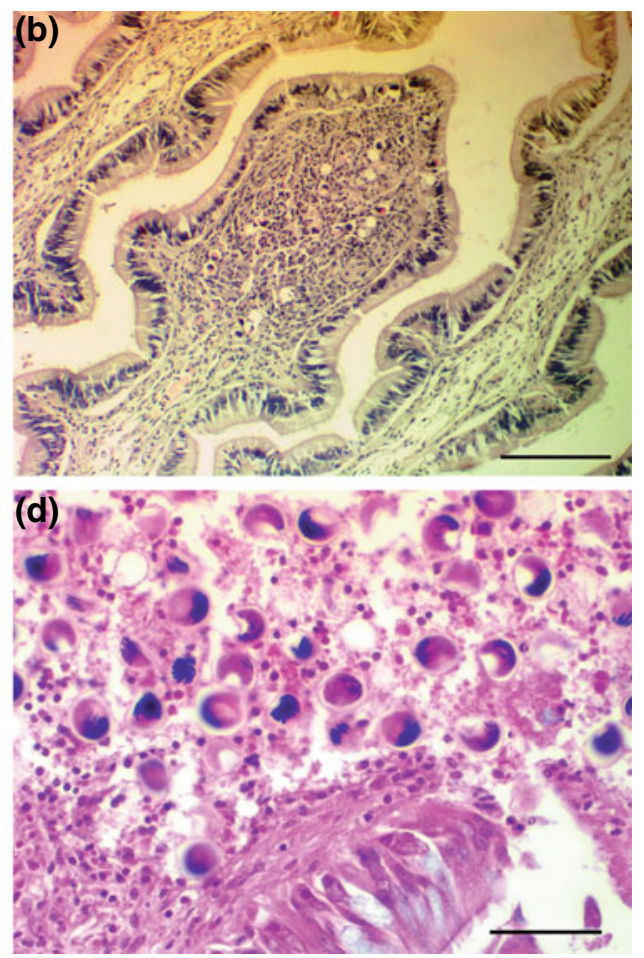

shown in Fig. 17.4b. Note the sporocysts in the loose connective tissue of the primary folder and throughout the epithelium. Scale bar: $50 \mu \mathrm{m}$. d Histological section of sporocysts located on the loose connective tissue of an infected intestine of $O$. maya. Note the destruction of the tissue organ architecture and loss of intestinal epithelium. Scale bar: $50 \mu \mathrm{m}$
Individual sporocysts not enclosed in cysts are located within epithelial cells of the mucous membrane and in the submucosal connective tissue of the caecum and intestine of O. maya (Fig. 17.4b-d). Pericyst reactions of connective tissue and hemocytic infiltration produce marked distension in the affected area (Fig. 17.4b). In the mucous membrane of the digestive tract, the sporocysts containing the infective stages (sporozoites) migrate through the epithelium causing degenerating and the death of the invaded cell (Fig. 17.4c). Periodically, necrotic portions of the caecum and infected intestinal epithelium are sloughed off and eliminated. In heavily infected hosts, most of the tissue is replaced by parasites, and loss of caecum, intestinal epithelium, and destruction of the organ tissue architecture can be observed (Fig. 17.4d). The damage may have detrimental effects on gastrointestinal function and a malabsorption syndrome is probably the result in a heavily infected host, which agrees with the observations by Gestal et al. (2002).

The digestive gland, the most prominent organ of $O$. maya, is brown in color and is located in the anterior half of the body (Fig. 17.5a). This is a branched tubular organ enclosed in a capsule of loose connective tissue with scarce smooth muscular fibers. Each tubule represents a functional unit and is composed of highly vacuolated polyhedral cells, which are seated in a thin basal lamina and defined apically the lumen of the tubule (Fig. 17.5b). The organ's function is related to the digestive process, supplying most of the digestive enzymes (Domíngues et al. 2007; Aguila et al. 2007).

The presence of Aggregata sp. in the digestive gland of $O$. maya is less frequent than in the caecum and intestine. However, sporogony stages can be seen in the epithelial cells of the hepatopancreatic tubes. Focal necrosis of the tubular epithelium and hemocytic infiltrations in the intertubular spaces are caused by the presence of sporogony stages. The severity of the damage is related to the infection level, which can cause degeneration of epithelial cells and atrophy of the organ (Fig. 17.5c, d).

As in other coleoids, a single pair of well-vascularized gills suspended in the mantle cavity permits the respiratory exchange of $O$. maya with the environment (Fig. 17.6a). The gill has primary lamellae that extend perpendicularly to the gill axis, forming inner and outer demibranches supported by cartilaginous rods. Each primary lamella is folded to form 
Fig. 17.5 a Digestive gland (arrow) in O. maya. Scale bar: $50 \mathrm{~mm}$. b Histological section of the digestive gland on a healthy O. maya. The lumen (l) of the tubules is lined by the epithelium (e) that it is supported by the basal lamina. Scale bar: $100 \mu \mathrm{m}$ c Histological section of the digestive gland showing a focal necrosis (arrow) in the tubular epithelium. Scale bar: $100 \mu \mathrm{m}$. d Histological section of the digestive gland on an infected $O$. maya with Aggregata sp. Note the focal necrosis and uninucleate sporoblasts on the epithelium. Scale bar: $50 \mu \mathrm{m}$
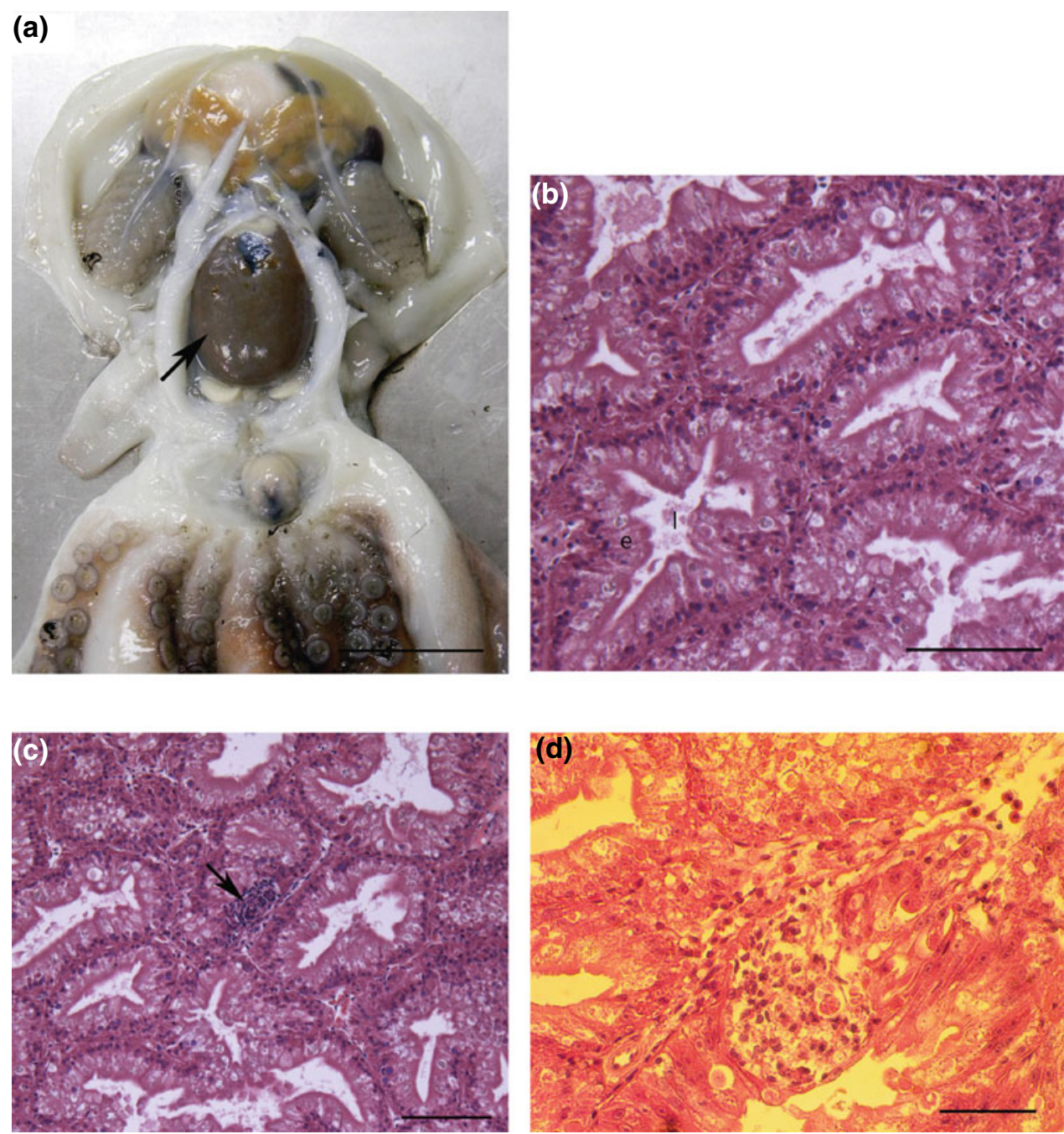

secondary lamellae that are partially partitioned by a septum. A branched arrangement of the secondary lamellae originates the tertiary lamellae (Fig. 17.6b). The secondary and tertiary lamellae are lined by a thin epithelium in a concave inner and convex outer side. Between inner and outer parts, the hemolymph runs in lacunae facilitating the gas exchange (Fig. 17.6c).

The gills are the target organs of most parasite species in O. maya. Copepods of the genus Octopicola are frequent parasites of the gill tissue. The number of parasites varies according to locality and climatic season, but generally, the abundance is high. Infections by these copepods cause hemocytic infiltration between the inner and outer layers of the secondary and tertiary lamellae, with connective tissue proliferation and lamella fusion (Figs. 17.7a, b). The damage is greater when the abundance of parasites increases, compromising large areas of gill tissue. The second more frequent parasite that infects the gills of $O$. maya is an unidentified larval cestode. The presence of plerocercoids in the gill tissue is more frequent in primary lamellae and less frequent in secondary lamellae, where the cestodes induce connective tissue proliferation with hemocytic infiltration (Fig. 17.7c, d). The compromised area depends on the number of cestodes and the magnitude of host tissue reaction, but in heavily infected hosts the hemolymph flow may be reduced considerably, affecting physiological processes.

A Cryptogonimidae trematode has been identified in gills from $O$. maya. This parasite is less frequent than copepods and cestodes, and the histological damage associated with it is more focal. The metacercariae show a preference for the primary lamellae, producing distention and hemocytic infiltration (Fig. 17.8a, b).

Extraintestinal sporogonia of Aggregata sp. have been observed in the gills of O. maya. The infected hosts show 
Fig. 17.6 a Gills in O. maya (arrow). b Histological section of gill on a healthy $O$. maya. Note the branching arrangement of the lamellae. Scale bar: $500 \mu \mathrm{m}$. c Histological section of a gill of a healthy $O$. maya showing the epithelium (arrow). Scale bar: $100 \mu \mathrm{m}$
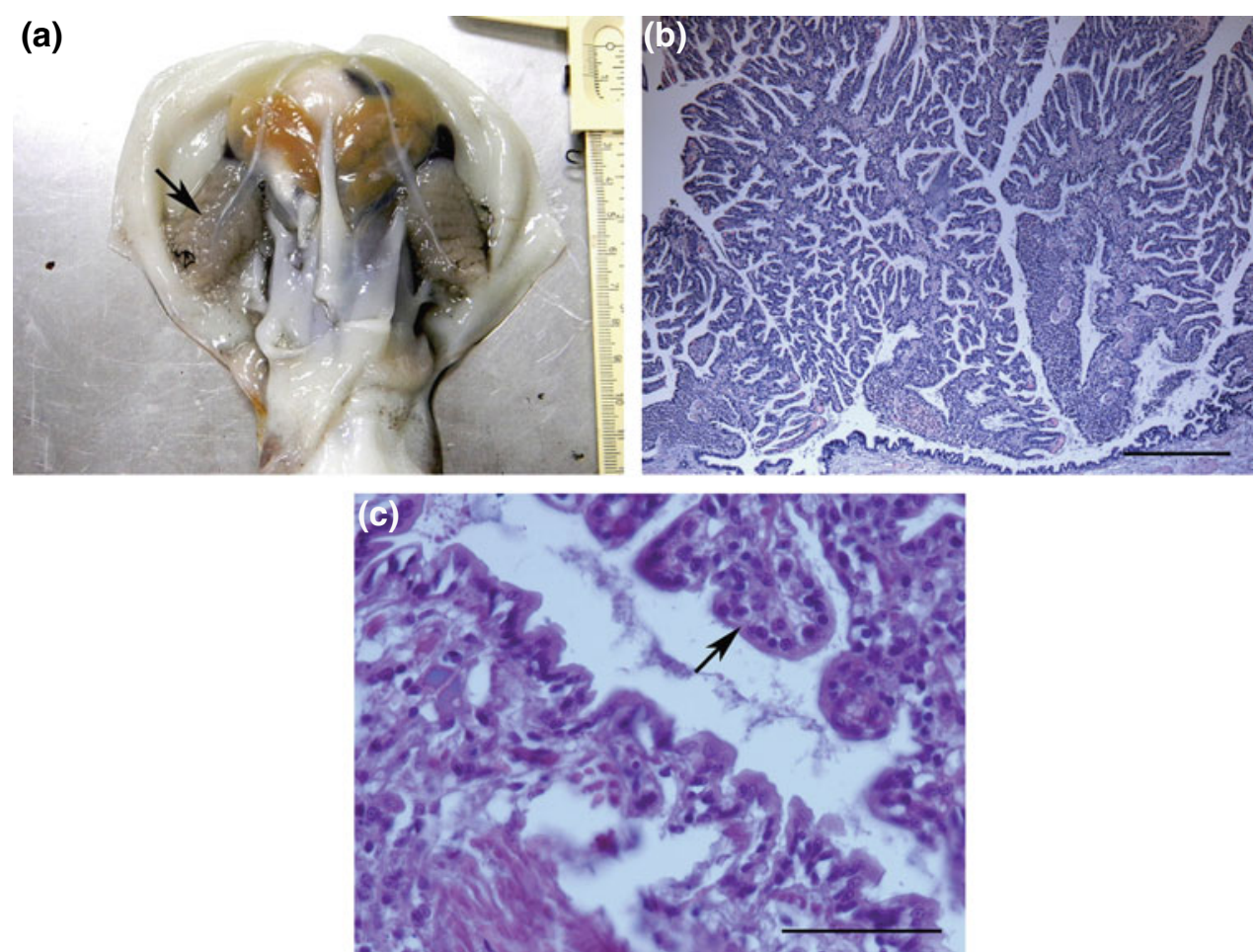

Fig. 17.7 a Gill section of $O$ maya with an Octopicola copepod (Co) producing distention of lacunae (la) and hemocytic infiltration. Scale bar: $100 \mu \mathrm{m}$. b Higher magnification of Fig. 17.7a. Note the arrangement of the host tissue to encapsulate the copepod (Co). Scale bar: $50 \mu \mathrm{m}$. c Gill section of Octopus maya with a strong hemocytic reaction around an unidentified larval cestode (c). Scale bar: $200 \mu \mathrm{m}$. d Higher magnification of the gill tissue, showing proliferation of connective tissue $(\mathrm{Ct})$ around unidentified larval cestode. Scale bar: $50 \mu \mathrm{m}$
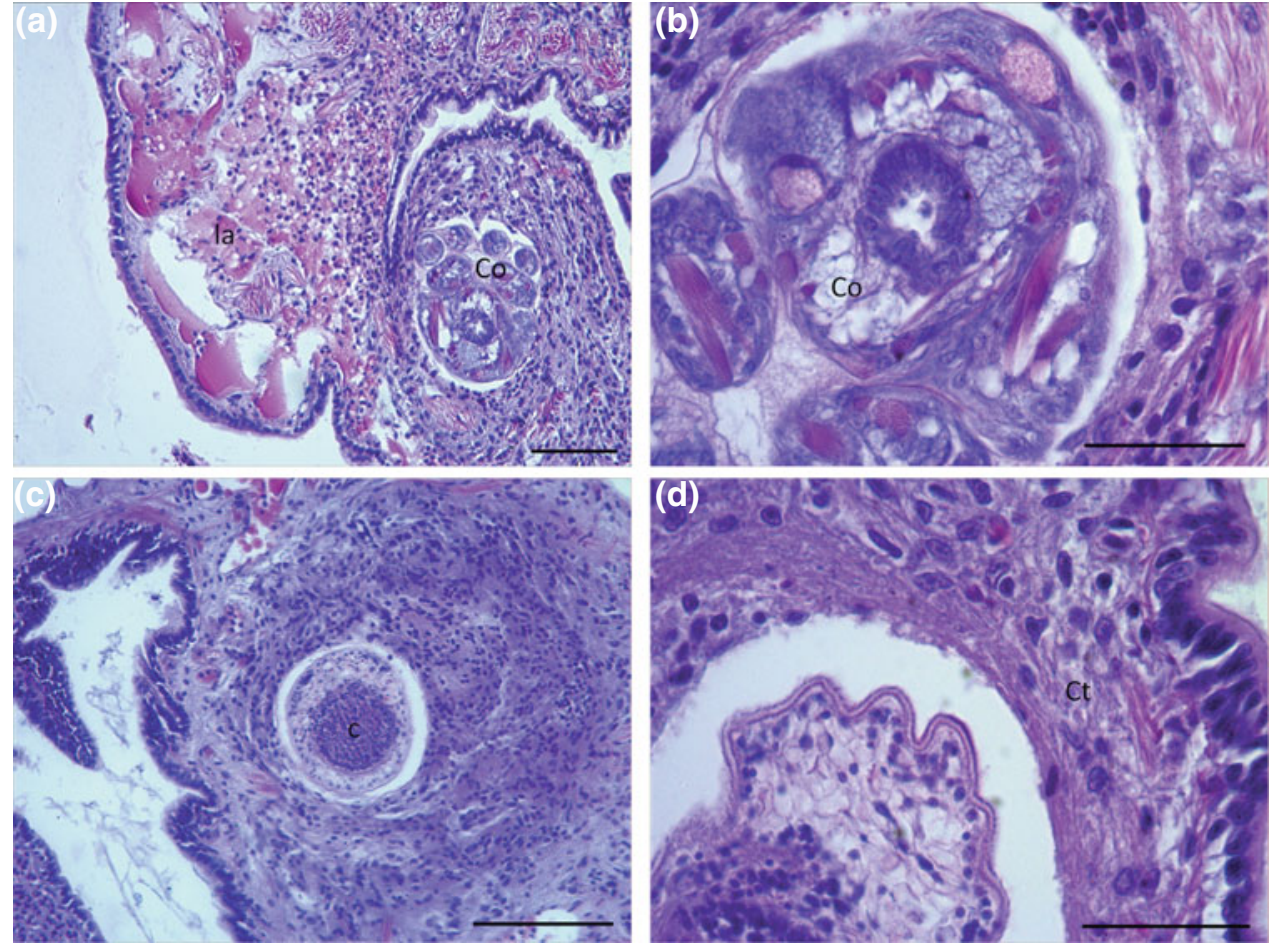
Fig. 17.8 a Gill section of $O$. maya with a Cryptogonimidae gen. sp. (arrows) producing distention of primary lamellae and hemocytic infiltration. Scale bar: $500 \mu \mathrm{m}$. b Higher magnification of Fig. 17.8a showing the sucker (su) of Cryptogonimidae trematode $(\mathrm{t})$. The tissue shows autolysis by poor fixation. Scale bar: $50 \mu \mathrm{m}$. c Gill section of Octopus maya with oocysts (Oo) of Aggregata sp. Scale bar: $200 \mu \mathrm{m}$. d Higher magnification of Fig. 17.8c showing distention of the lamellar epithelium (arrow) caused by the presence of numerous uninucleate sporoblasts inside the oocyst (Oo). Scale bar: $500 \mu \mathrm{m}$
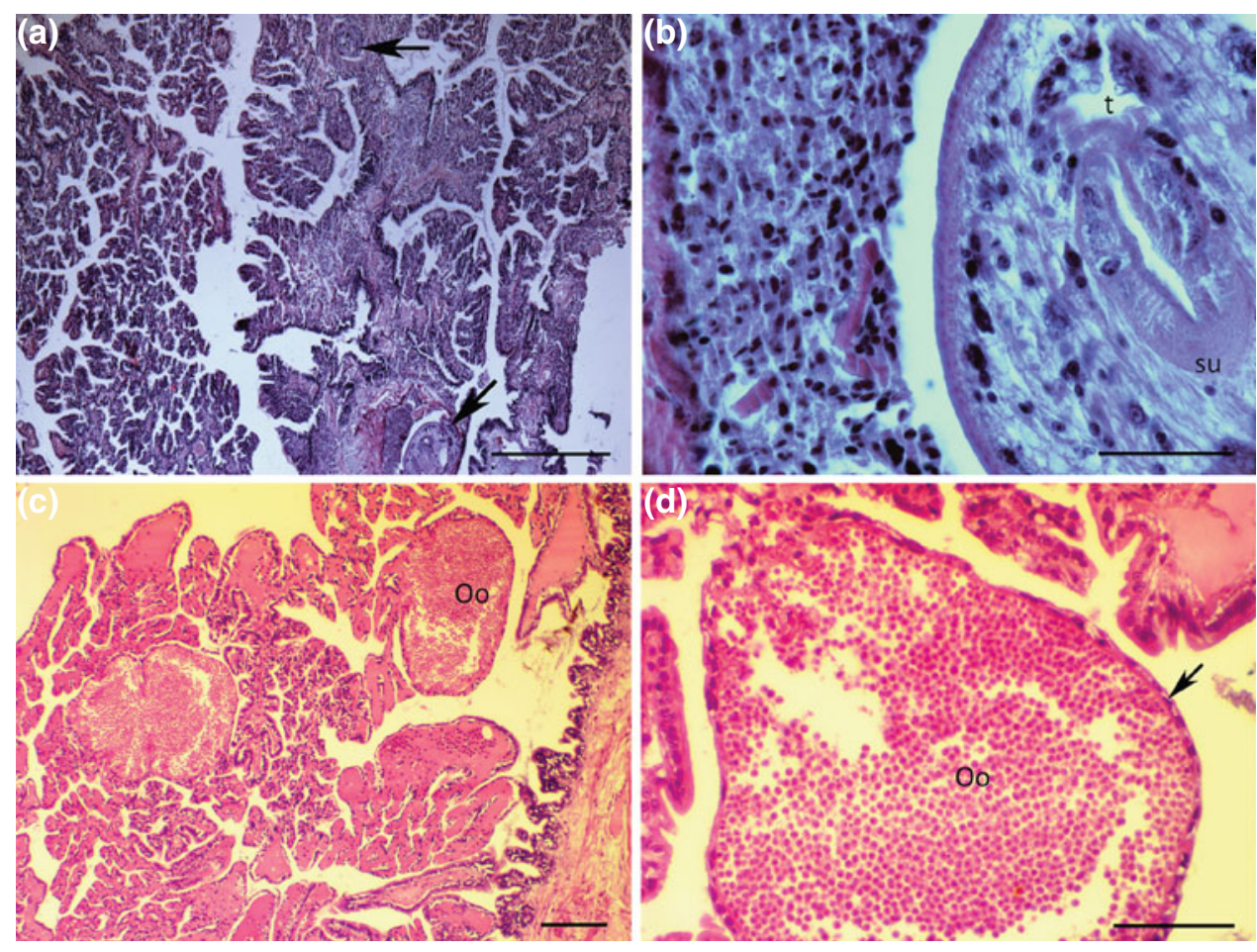

numerous oocysts in the gills' secondary and tertiary lamellae (Fig. 17.8c). Each oocyst containing high numbers of uninucleate and less binucleate sporoblasts is surrounded by a thin wall and grows among inner and outer epithelium of secondary and tertiary lamellae (Fig. 17.8d). The larger oocysts disrupt the normal branched pattern of the gill and can cause mechanical compression in adjacent lamellae, likely affecting hemolymph flow. The impact of Aggregata sp. infections in $O$. maya has not been yet studied. However, the histological damages observed in the intestine and gills suggest a high pathogenic capability of Aggregata sp. that may affect the physiology and body condition on the infected hosts.

Like other cephalopods (Hochberg 1990), the excretory organs of $O$. maya exhibit dicyemids attached principally to the renal appendages (Fig. 17.9a, b). The presence of these vermiform stages is not associated to excretory tissue damages (Fig. 17.9c), and it is generally accepted that the dicyemids are symbionts that may facilitate host excretion of nitrogenized compounds by contributing to the acidification of the urine.

Idiopathic focal necrosis in the epithelium of renal tubules has been observed in $O$. maya at very low prevalence (Fig. 17.9d). However, no pathogen has been observed in the histological sections of affected organs, and there are no precedent studies pointing to a pathogen responsible for the latter. Therefore, further investigations to clarify the etiology of idiopathic necrosis in the renal appendages of $O$. maya are still needed.

\subsection{Pathogens and Related Diseases in the Jumbo Squid Dosidicus Gigas}

The jumbo flying squid Dosidicus gigas, the other non-European cephalopod treated in this chapter, also harbors some parasites and diseases that affect tissues and organs (Pardo-Gandarillas et al. 2009; Iannacone and Alvariño 2009). The buccal mass, the first organ of the digestive system, is heavily infected by an unidentified larval cestode. Plerocercoids can be observed among the acini of anterior salivary glands and under the mucosal epithelium (Fig. 17.10a, d). The damages on affected tissue are related to the infection level. At low parasite numbers, the damages are local, consisting of focal modifications of tissue architecture and proliferation of connective tissue (Fig. 17.10b, c). Higher parasite numbers can cause degeneration and necrosis in the secretory epithelium of anterior salivary glands, which is replaced by parasites and fibro-connective tissue (Fig. 17.10 d). In severe infections ( $>20$ parasites per host), the secretory tissue of the salivary gland may be severely affected, greatly reducing saliva production. This could have a negative effect on nutrition and therefore on the body weight and general physiological condition of the host. 
Fig. 17.9 a Renal organs in $O$. maya (arrow). Scale bar: $50 \mathrm{~mm}$. b Section of renal tissue of healthy $O$. maya showing dicyemids symbionts (arrow) in the lumen of the tubules. (Ep) Epithelium of the renal tubules. Scale bar: $250 \mu \mathrm{m}$. c Higher magnification of Fig. $17.9 \mathrm{~b}$ showing the nucleus of epithelial cells (Ep) of the renal tubules and the presence of dicyemids (Di) in the lumen. Scale bar: $50 \mu \mathrm{m}$. d Section of renal tissue with idiopathic focal necrosis (arrow) in the excretory epithelium. Scale bar: $200 \mu \mathrm{m}$
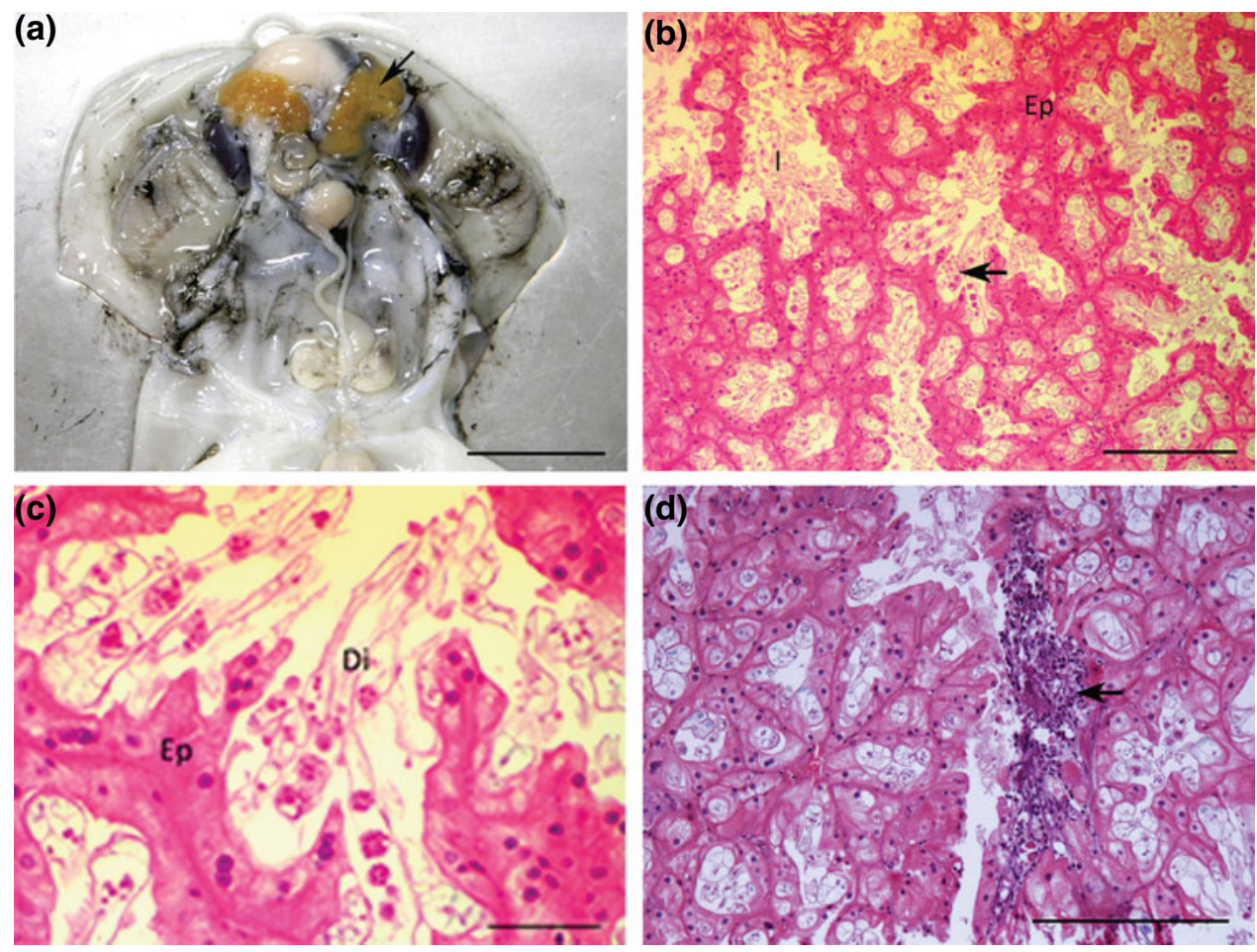

Fig. 17.10 Histological section of buccal mass from Dosidicus gigas. a Acini of the anterior salivary gland $(\mathrm{Sg})$; one of them is discharging the mucous secretion through the epithelium (arrow). Scale bar: $250 \mu \mathrm{m}$. b Anterior salivary gland with moderate infection by larval cestode (c). Scale bar: $250 \mu \mathrm{m}$. c Anterior salivary gland showing proliferation of connective tissue (arrow) around a larval cestode. Scale bar: $100 \mu \mathrm{m}$. d Anterior salivary gland $(\mathrm{Sg})$ heavily infected with larval cestodes. Secretory tissue is strongly reduced and has been replaced by parasites and fibro-connective tissue (left). Scale bar: $500 \mu \mathrm{m}$
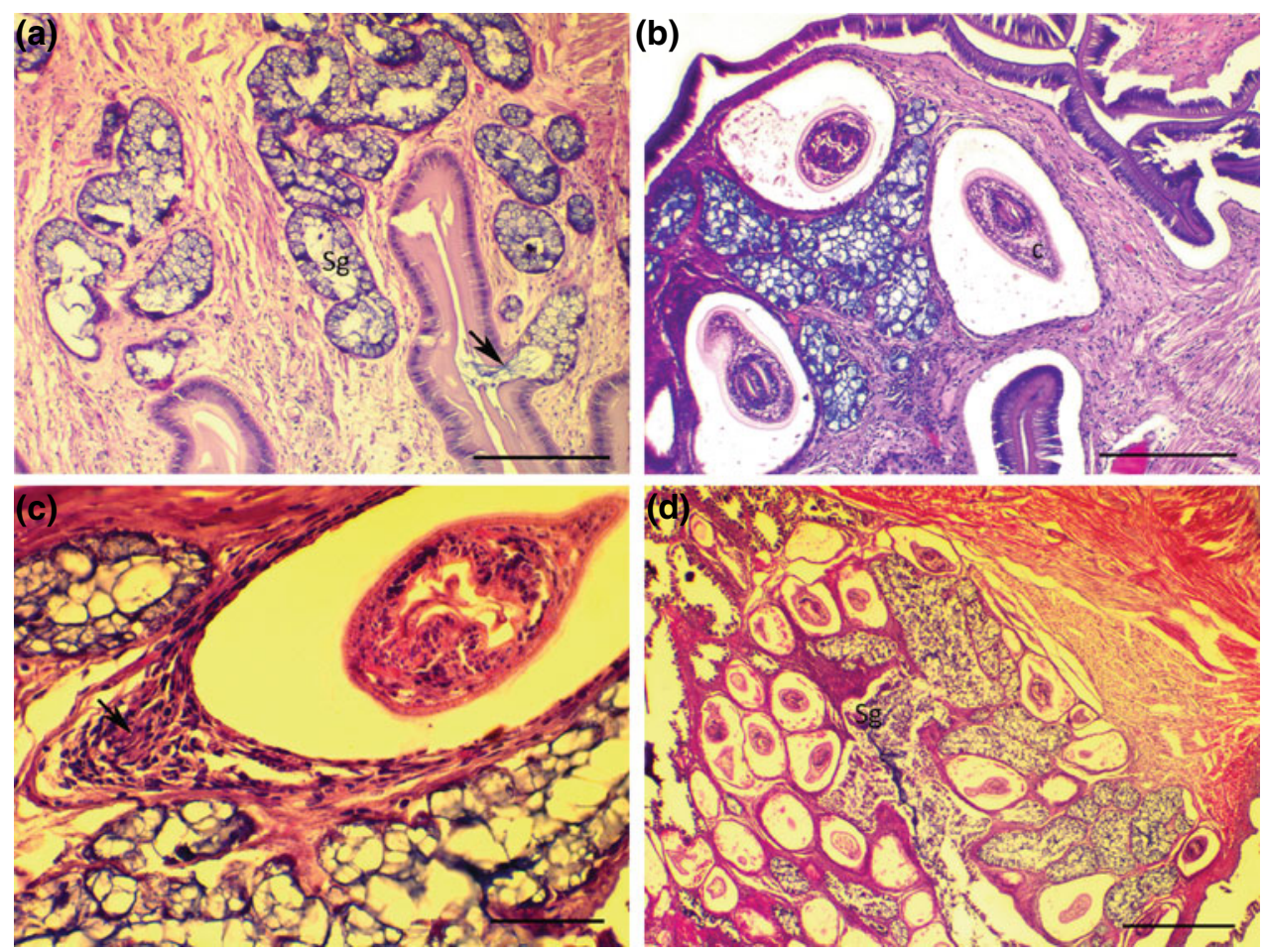
Fig. 17.11 Histological sections of buccal mass from male $D$. gigas showing spermatophores $(\mathrm{Sp})$ attached to the mucosa. a The epithelium and lamina propria are damaged and a hemocytic reaction $(*)$ is visible in the affected area. Scale bar: $250 \mu \mathrm{m}$. b Hemocytic infiltration $(*)$ around the epithelium, lamina propria and adjacent acinus, affected. Scale bar: $250 \mu \mathrm{m}$
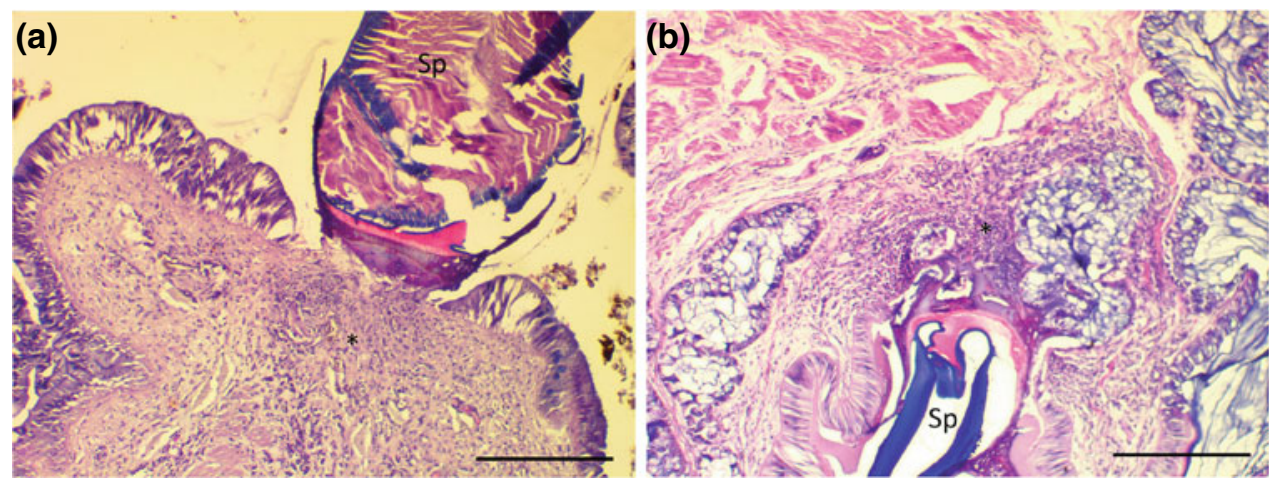

In males of $D$. gigas, some spermatophores can be found attached to the mucosa of the buccal mass (also in the gills, see below) causing ulcers that penetrate into the submucosa (Fig. 17.11a, b). The epithelium and basal lamina are damaged at the site of attachment, and hemocytic infiltration can be seen around the injury. A plausible explanation for this interesting and unusual condition is that the spermatophores probably belong to another male and act as foreign bodies when coming into contact with the tissues of the receptor host.

The general morphology of the caecum in D. gigas is similar to that of O. maya. Primary folds arise from the inner margin of the caecum wall and are protruded into the lumen.
The secondary folds stem from both sides of the primary folds and perpendicularly to their axes (Fig. 17.12a). Two kinds of parasites, nematode and cestode, infect the caecum. Anisakidae nematodes have been found encysted in the caecum wall, where a hemocytic infiltration causes distention of the connective tissue (Fig. 17.12b). In contrast, plerocercoids of an unidentified cestode are very frequent in the basal, medial, and apical zones of the primary folds of the caecum causing degeneration and focal necrosis (Fig. 17.12c, d).

In the intestine, two morphotypes of an unidentified cestode were found (Fig. 17.13a, b). One large morphotype
Fig. 17.12 Histological section of the coiled caecum of $D$. gigas. a Healthy tissue showing the external wall with primary longitudinal folds (Pf) and secondary folds (arrow). Scale bar: $250 \mu \mathrm{m}$. b A larvae of Anisakidae nematode (arrow) encysted in the wall of the coiled caecum. Scale bar: $250 \mu \mathrm{m}$. c Coiled caecum showing unidentified larval cestodes (arrow) infecting the loose connective tissue of primary fold. Scale bar: $250 \mu \mathrm{m}$. d Primary fold showing degenerated tissue and focal necrosis (arrow) in the loose connective tissue. Scale bar: $250 \mu \mathrm{m}$
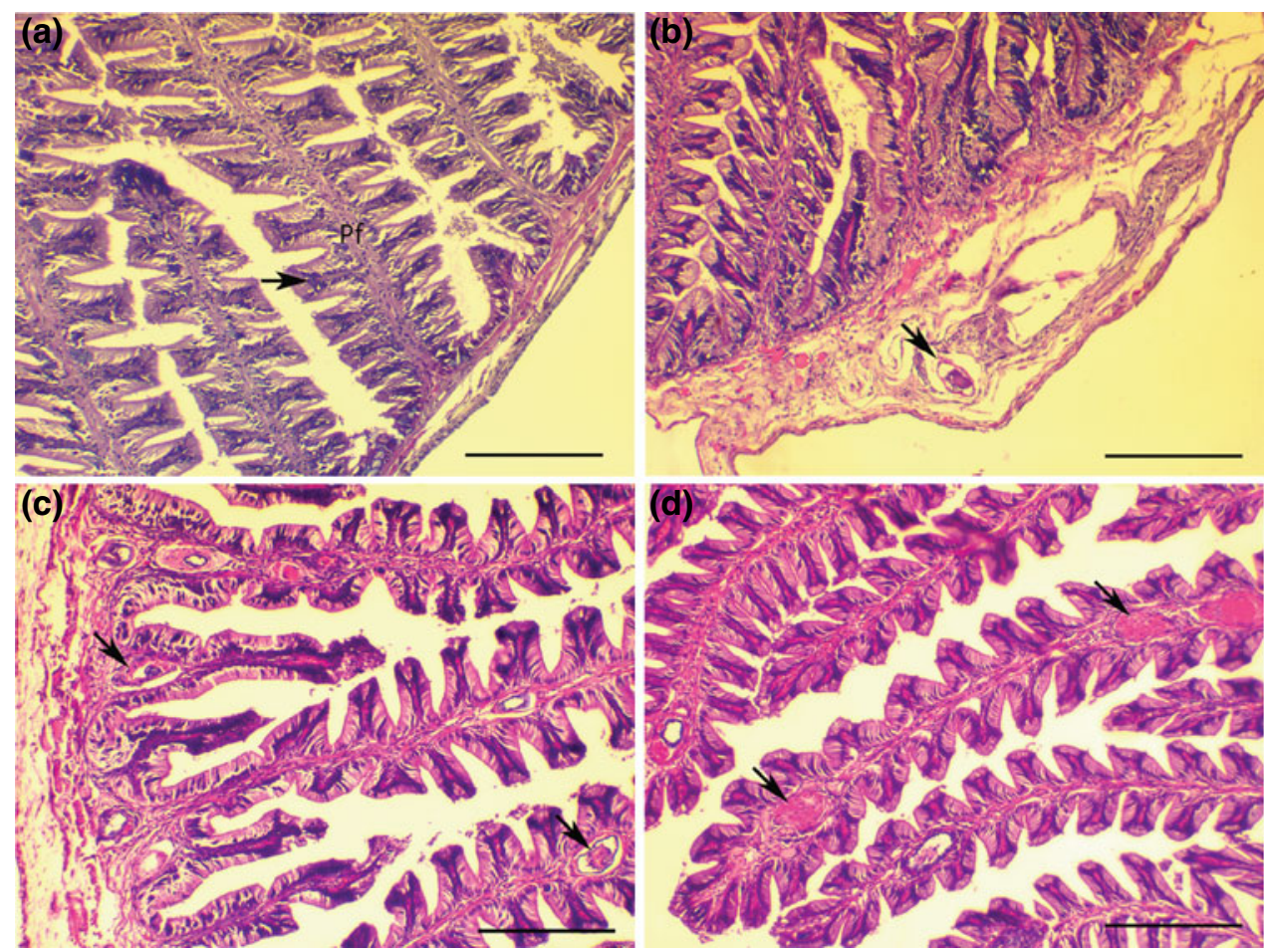

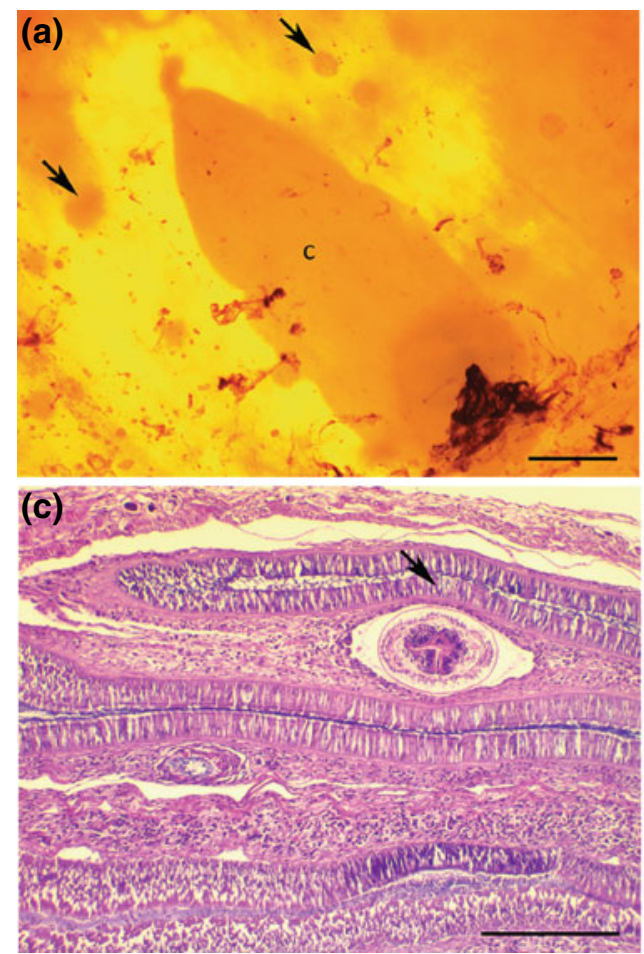

Fig. 17.13 Wet mount and histological sections of intestine from $D$. gigas. a Fresh intestine infected with two morphotypes of unidentified larval cestodes. One larger morphotype (c) inside the intestine, and second smaller morphotype (arrows) encysted in the intestine wall. Scale bar: $500 \mu \mathrm{m}$. b Histological section of the intestine from Fig. 17.13a showing the two morphotypes of unidentified larval

can be found in the lumen of the intestine, while a smaller and more abundant morphotype infects not only the intestinal wall and folds but also the caecum primary folds and digestive gland. No damage has been associated with the presence of the larger morphotype cestode in the intestinal lumen. The smaller morphotype produces a protrusion of the intestinal epithelium by an expansion of a subjacent connective tissue (Fig. 17.13c). The presence of plerocercoids in the corion of the intestinal fold triggers the host's cellular response, and the fibroblastic cells come to organize themselves around the parasite to encapsulate it, causing distention (Fig. 17.13d). Like in the caecum, focal necrosis and degenerated tissue can be seen near the plerocercoid, probably caused by the secretions of the parasite. The presence of this smaller morphotype of plerocercoid in digestive gland was infrequent, and no damage or alteration of the normal tissue architecture was related to the presence of parasite (Fig. 17.14a, b).

Despite the macroscopic differences in gill morphology between $D$. gigas and $O$. maya, microscopically they share a
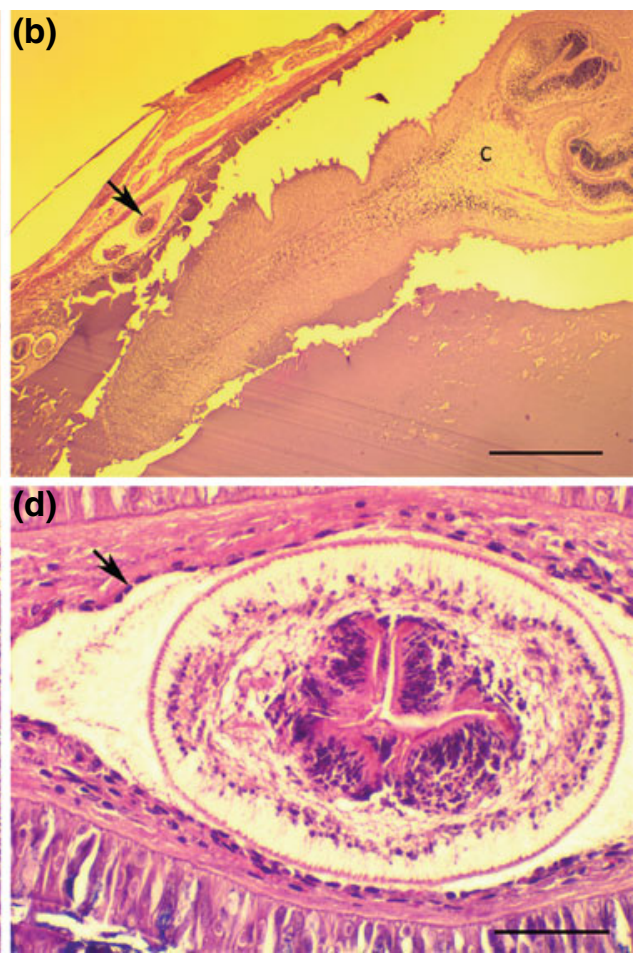

cestodes. Scale bar: $500 \mu \mathrm{m}$. c Larval cestode of the smaller morphotype infecting the intestinal submucosa. Note the protruded intestinal epithelium (arrow) by expansion of subjacent connective tissue. Scale bar: $250 \mu \mathrm{m}$. d Higher magnification of Fig. 17.13c showing the flattened nuclei of fibroblastic cells organized around the larval cestode. Scale bar: $100 \mu \mathrm{m}$

similar basic morphology. The primary lamellae form the secondary ones, and these form the tertiary ones on a continuous fold pattern. The main morphological difference is the fanlike fold pattern in D. gigas in comparison to the branched arrangement pattern in $O$. maya (Fig. 17.15a, b). As mentioned above, spermatophores were found attached to the gills of male specimens (Fig. 17.15c). The number of spermatophores in the gills varies greatly but is generally high, causing compression and modification of the fanlike folded pattern of lamellae (Fig. 17.15d).

Nodular lesions in the epithelium of secondary and tertiary lamellae were observed and associated with the presence of coccidian (Fig. 17.16a). Aggregata sp. sporocysts are phagocytized by hemocytes and surrounded by strong hemocytic infiltration (Fig. 17.16b). The space between inner and outer epithelium in the infection sites is distended and filled with proliferative connective tissue, reducing its gas exchange capability. In addition, oocysts containing numerous uninucleate sporoblasts are present and produce distention of the lamellae (Fig. 17.16c). Multiple oocysts of 
Fig. 17.14 Histological sections of digestive gland from $D$. gigas. a Healthy tissue showing the tubular epithelium (arrow) and the lumen of the tubules (1). Scale bar: $250 \mu \mathrm{m}$. b Unidentified larval cestode (arrow) among tubules of the digestive gland. Scale bar: $250 \mu \mathrm{m}$
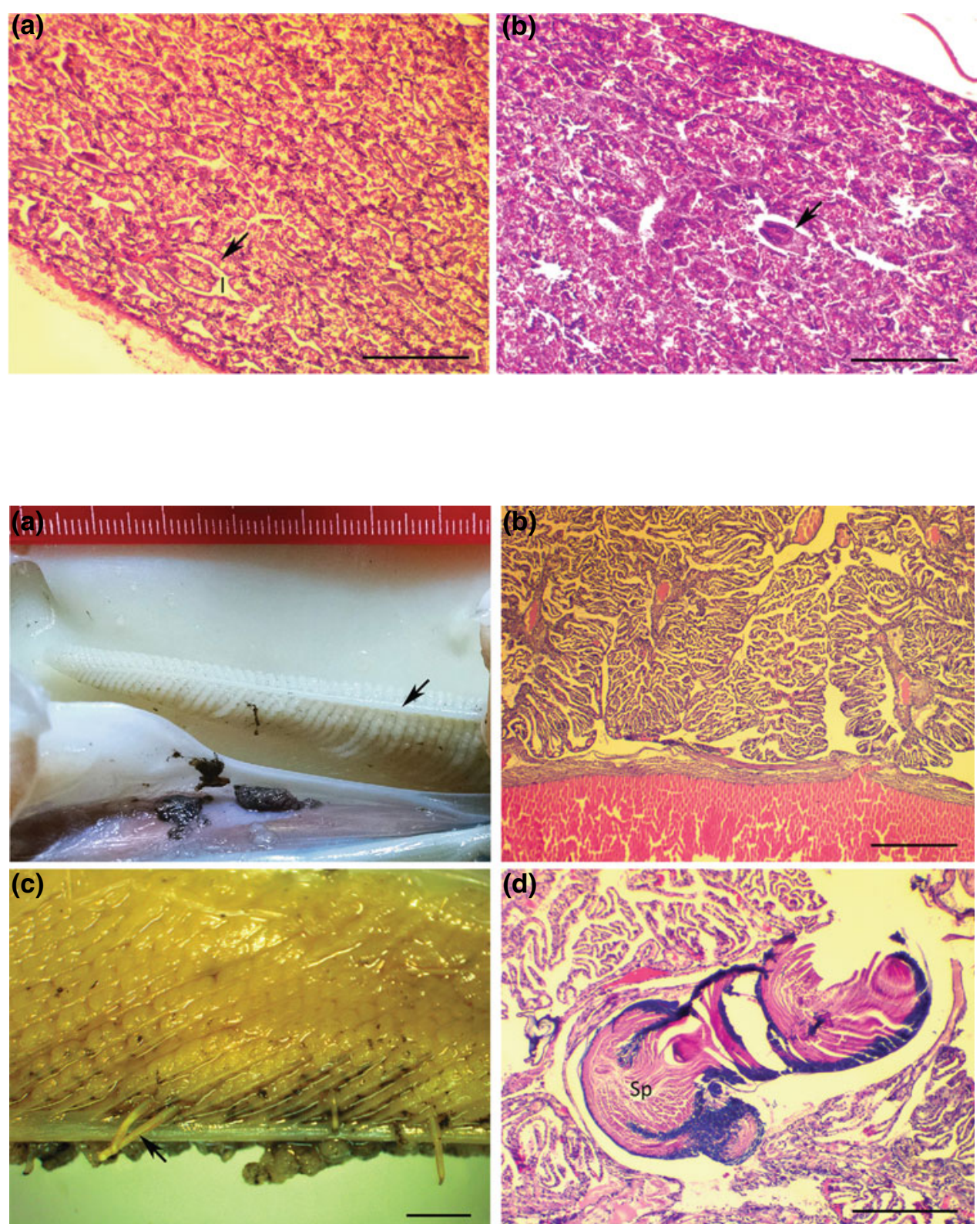

Fig. 17.15 Macroscopic view and histological section of gill from D. gigas. a Macroscopic view of fold pattern and primary efferent vessel (arrow) in gill. b Histological section showing the fold pattern and primary efferent vessel (lower view). Scale bar: $500 \mu \mathrm{m}$. c Spermatophores (arrow) attached to the gill in mature male of $D$. gigas. Scale bar: $5 \mathrm{~mm}$. d Histological section showing the modified architecture of the gill caused by the attached spermatophore (Sp). Scale bar: $250 \mu \mathrm{m}$ different sizes are present in the same lamella, separated by a thin wall (Fig. 17.16d).

The mantle of D. gigas, as in other cephalopods, is mainly a muscular layer lined with a delicate yet sophisticated skin, which functions as the primary barrier against pathogens and environmental stressors. For this reason, some pathogens settle in this organ as the first site of infection, facilitating the entry of opportunistic pathogens. This is the case of Anisakidae nematodes, whose larvae penetrate through the skin and encyst in the mantle musculature until the final host devours the squid and the life cycle is completed. Whitish and slightly protuberant nodules containing Anisakidae nematodes are visible by gross observation in the mantle of D. gigas (Fig. 17.17a). A connective tissue reaction and hemocytic infiltration surround the nematodes (Fig. 17.17b), but the organization of the host's tissue response may be associated to the time of permanence of the larva. A less organized inflammatory response could be associated with newly migrating larvae (Fig. 17.17c).

In the musculature of the mantle, and to some extent in that of the tentacles, there are also nodules of variable size, well delimited, and brown in color (Fig. 17.18a). These nodules contain a homogeneous hyaline material, with very 
Fig. 17.16 Histological section of gill from D. gigas. a Nodular lesion (arrow) and oocysts of Aggregata sp. (arrowhead) in gill. Scale bar: $500 \mu \mathrm{m}$. b Proliferative reaction around the free sporocysts of Aggregata sp. (arrow). Scale bar: $30 \mu \mathrm{m}$. c Oocysts (Oo) of Aggregata sp. among inner and outer epithelium (arrow). Scale bar: $100 \mu \mathrm{m}$. d Higher magnification of Oocysts (Oo) in gill. Each oocyst, containing many uninucleate and some binucleate sporoblasts, are delimited by a thin wall (arrow). Scale bar: $30 \mu \mathrm{m}$
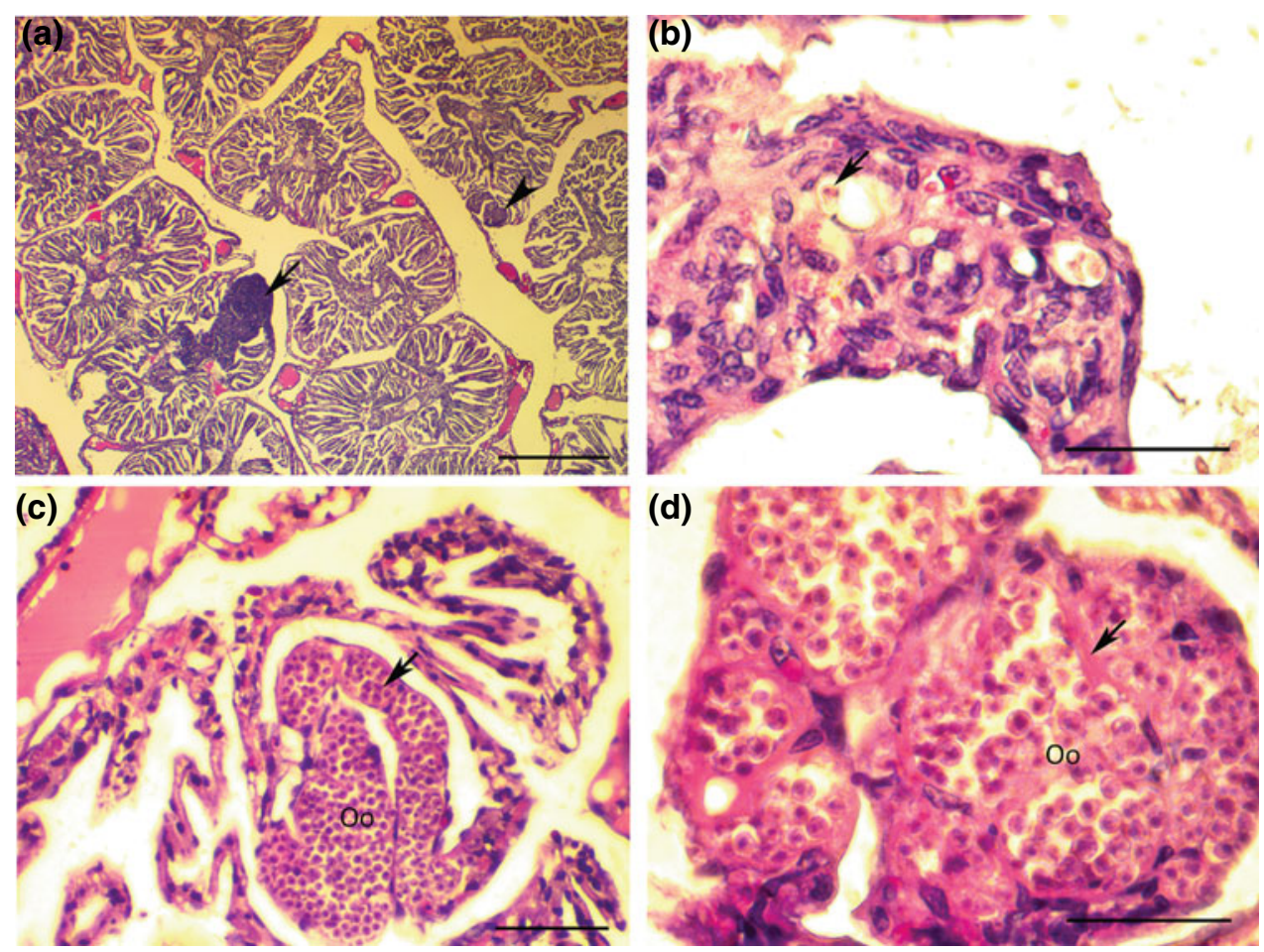

Fig. 17.17 Macroscopic view and histological sections of mantle from $D$. gigas. a A larva of Anisakidae nematode (arrow) encysted in the mantle

musculature. Note the host's tissue response forming a white ring around the nematode. Scale bar: $100 \mu \mathrm{m}$. b Histological section of the tissue that was showed in Fig. 17.17a. The nematode (central view), sectioned transversally, is rounded by an organized connective tissue and hemocytic infiltration. Scale bar: $500 \mu \mathrm{m}$. c Degeneration of muscular fibers and focal necrosis with hemocytic infiltrate in the mantle muscle (M) caused by the presence of Anisakidae nematodes (arrow). Scale bar: $250 \mu \mathrm{m}$
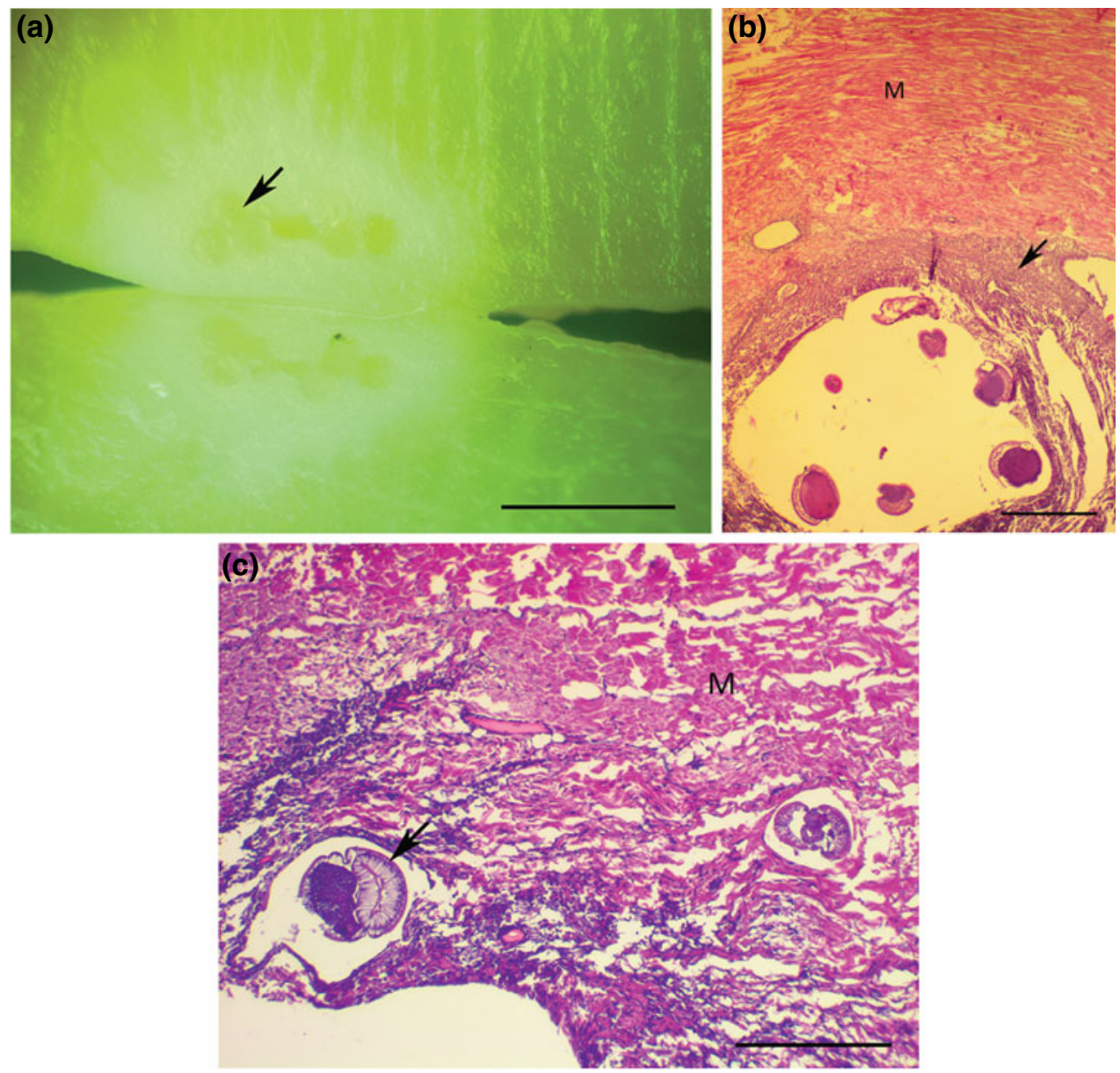
Fig. 17.18 Macroscopic view and histological sections of mantle from $D$. gigas.

a Macroscopic view of a nodule in the mantle (arrow), just below the epithelium. The tissue has been cut transversally to facilitate the view. Scale bar: $500 \mu \mathrm{m}$. b Histological section of the mantle showing a hyaline nodule (arrow). Scale bar: $500 \mu \mathrm{m}$. c Higher magnification of Fig. 17.18b showing the hyaline material (left) and focal necrosis (n) surrounded by fibroblasts and pigmented cells (arrow). Scale bar: $100 \mu \mathrm{m}$. d Giant cells with phagocytized bacteria (*) and colonies of bacteria (arrow) free among connective tissue fibers. Note the organization of the tissue around the bacterial colonies. Scale bar: $100 \mu \mathrm{m}$
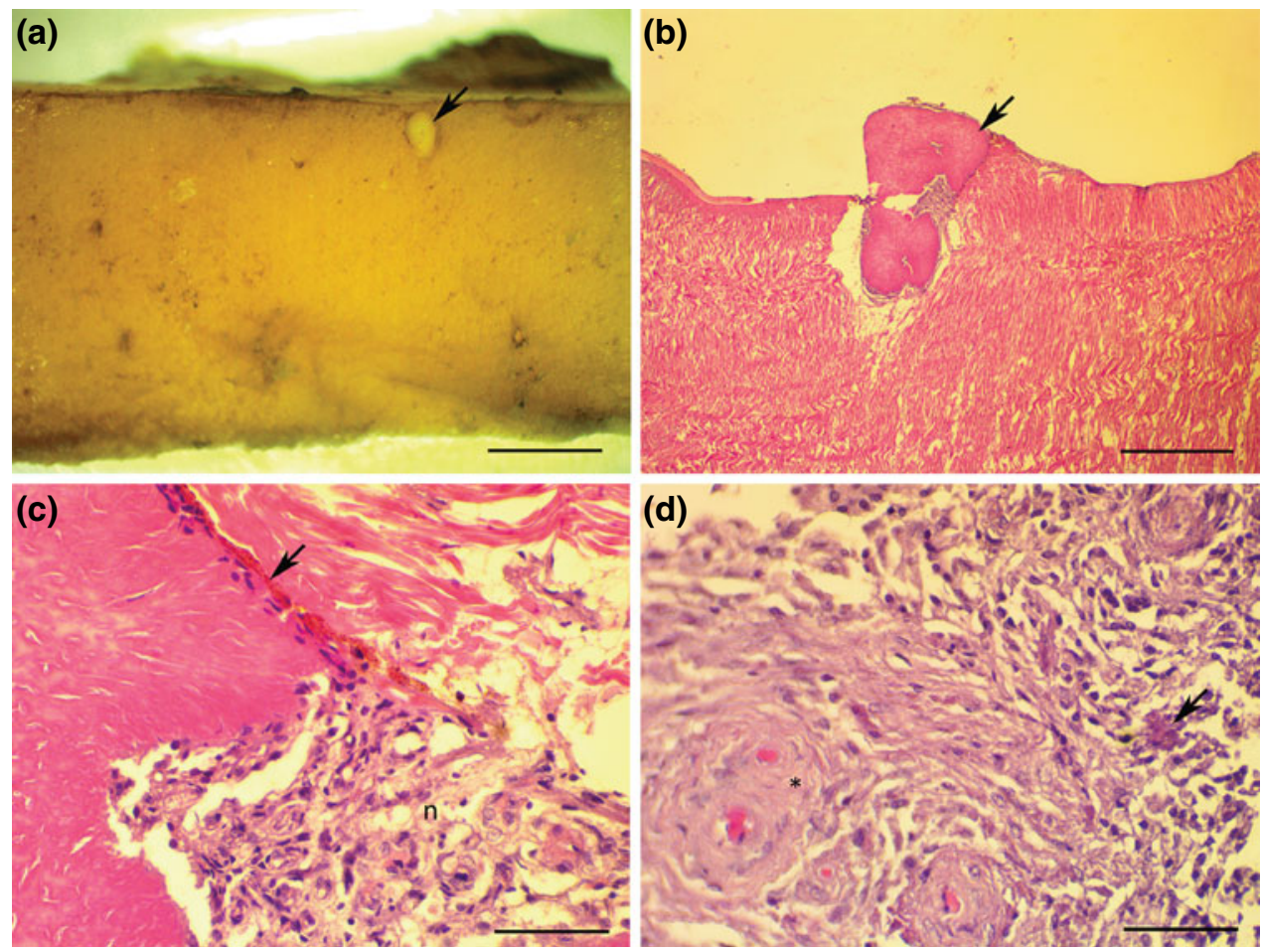

few cells inside of them (Fig. 17.18b), which could be some type of degraded residue generated during nematode migration. The nodules are covered by a layer of fibro-connective tissue and pigmented cells that give it the brown color (Fig. 17.18c). In some areas, foci of necrosis and connective tissue proliferation can be observed around bacterial colonies, suggesting a subsequent infection after nematode larvae migration (Fig. 17.18d).

\subsection{Concluding Remarks}

It is evident that there are severe pathological affections in wild cephalopods, with the most serious being those occurring in the digestive system, particularly in the buccal mass. In both cephalopods studied here, heavy infection of cestodes was identified as the etiological origin. Although the severity of infection depends directly on the infection degree, higher parasite numbers can cause degeneration and necrosis in the secretory epithelium and salivary glands, so that nutrients absorption can be affected and in consequence the entire host condition. This affection, nonetheless, can be easily avoided in captive cephalopods. The cephalopods in these infections are playing as second intermediate host of the cestodes; being copepods or small crustaceans the first intermediate hosts and sharks or rays the definitive host, so that water quality control and captivity food control will avoid reinfections that are undoubtedly happening in natural environments. With cestodes, most metazoan parasites occurring in the digestive system any other host tissue can be controlled following the same practices.

Coccidians of the genus Aggregata were also common to both cephalopod species, similarly to cestodes, the severity of the damage will depend on the infection degree. In $O$. maya, the most affected organ was the intestine while in $D$. gigas it was the gills. Aggregata are common to most cephalopods studied till now and the diseases associated with its presence have been addressed in several hosts.

Although it is known that in captivity an ectoparasitic protozoan Ichthyobodo necator can infect the skin of $O$. maya and several species of bacteria including Vibrionaceae also represent a major threat, we did not find histopathological evidence of their presence in wild octopus $O$. maya or the jumbo squid Dosidicus gigas.

\section{References}

Aguila J, Cuzon G, Pascual C, Domingues PM, Gaxiola G, Sánchez A, Maldonado T, Rosas C (2007) The effects of fish hydrolysate (CPSP) level on Octopus maya (Voss and Solis) diet: digestive enzyme activity, blood metabolites, and energy balance. Aquaculture 273:641-655

Boyle P, Rodhouse P (2005). Cephalopods: ecology and fisheries. Blackwell Science, p 467 
Domingues PM, López N, Muñoz JA, Maldonado T, Gaxiola G, Rosas C (2007) Effects of a dry pelleted diet on growth and survival of the Yucatan octopus, Octopus maya. Aquacul Nutr 13:273-280

Estévez J, Pascual S, Gestal C, Soto M, Rodríguez H, Arias C (1996) Aggregata octopiana (Apicomplexa: Aggregatidae) from Octopus vulgaris off NW Spain. Dis Aquat Org 27:227-231

Gestal C, Abollo E, Pascual S (2002) Observations on associated histopathology with Aggregata octopiana infection (Protista: Apicomplexa) in Octopus vulgaris. Dis Aquat Org 50:45-49

Gestal C, Pascual S, Corral L, Azevedo C (1999) Ultrastructural aspects of the sporogony of Aggregata octopiana (Apicomplexa, Aggregatidae), a coccidian parasite of Octopus vulgaris (Mollusca, Cephalopoda) from NE Atlantic Coast. Eur J Protistol 35:417-425

Hochberg FG (1990) Diseases of Mollusca: Cephalopoda. Diseases caused by protistans and metazoans. In: Kinne O (ed) Diseases of marine annimals, vol III. Biologische Anstalt Helgoland, Hamburg, pp 47-227

Open Access This chapter is licensed under the terms of the Creative Commons Attribution 4.0 International License (http://creative commons.org/licenses/by/4.0/), which permits use, sharing, adaptation, distribution and reproduction in any medium or format, as long as you give appropriate credit to the original author(s) and the source, provide a link to the Creative Commons licence and indicate if changes were made.
Iannacone J, Alvariño L (2009) Catastre of endoparasite fauna of jumbo flying squid Dosidicus gigas (Cephalopoda) in the north of Peru. Neotropl Helminthol 3:89-100

Morales-Bojórquez E, Pacheco-Bedoya J (2016) Jumbo squid Dosidicus gigas: a new fishery in Ecuador. Rev Fish Sci Aquacul 24:98-110

Pardo-Gandarillas M, Lohrmann K, Valdivia A, Ibañez C (2009) First record of parasites of Dosidicus gigas (d'Orbigny, 1835) (Cephalopoda: Ommastrephidae) from the Humboldt Current system off Chile. Rev Biol Mar Oceanogr 44:397-408

Roper C, Nigmatullin C, Jereb P (2010) Family Ommastrephidae. In: Jereb P, Roper CFE (eds) Cephalopods of the World. An annotated and illustrated catalogue of species known to date. FAO Species catalogue for Fisheries Purposes. No 4, vol 2, FAO Rome, pp 269-347

Van Heukelem WF (1983) Octopus maya. In: Boyle PR (ed) Cephalopod Life Cycles, vol I. Academic Press, London, pp 311-323
The images or other third party material in this chapter are included in the chapter's Creative Commons licence, unless indicated otherwise in a credit line to the material. If material is not included in the chapter's Creative Commons licence and your intended use is not permitted by statutory regulation or exceeds the permitted use, you will need to obtain permission directly from the copyright holder. 